\title{
PENGARUH TATA KELOLA PERUSAHAAN TERHADAP MANAJEMEN LABA PADA PERUSAHAAN MANUFAKTUR YANG TERDAFTAR DI BURSA EFEK INDONESIA
}

\author{
Muhammad Zauqi Rachman
}

Trisakti School of Management, Jakarta, Indonesia

\begin{abstract}
Article Information
Received: 24 March 2020

Accepted: 29 May 2020

Published: 6 July 2020

DOI: $10.33555 /$ ijembm.v7i2.122

Corresponding Author:

Muhammad Zauqi Rachman Jakarta, Indonesia

Email: zauqrach888@gmail.com

ISSN $\quad 2338-8854$

eISSN 2620-9918
\end{abstract}

\begin{abstract}
ABSTRAK
Tujuan dari penelitian ini adalah untuk mendapatkan bukti tentang faktor yang mempengaruhi manajemen laba pada perusahaan manufaktur yang terdaftar di Bursa Efek Indonesia. Faktor tersebut meliputi keahlian keuangan komite audit, kepemilikan institusional, ukuran dewan komisaris, konsentrasi kepemilikan, direkur berkewarganegaran asing dan aktivitas dewan komisaris. Discretionary accrual digunakan sebagai proksi untuk manajemen laba. Sebanyak 101 perusahaan manufaktur yang terdaftar di Bursa Efek Indonesia pada periode tahun 2014 sampai dengan tahun 2016 menjadi sampel dalam penelitian ini dengan menggunakan metode purposive sampling. Regresi berganda sebagai metode analisis data digunakan dalam penelitian ini. Hasil penelitian menunjukkan bahwa keahlian keuangan komite audit, kepemilikan institusional, ukuran dewan komisaris, konsentrasi kepemilikan, dan direktur berkewarganegaraan asing tidak mempunyai pengaruh terhadap manajemen laba, sedangkan aktivitas dewan komisaris mempunyai pengaruh terhadap manajemen laba.
\end{abstract}

Kata kunci: Manajemen Laba, Ukuran Dewan Komisaris, Keahlian Keuangan Komite Audit, Discretionary Accrual

\begin{abstract}
This research aims to get the empirical evidence about the factors which will affect earnings management in manufacturing companies that listed in Indonesia Stock Exchange. These factors are audit committee financial expertise, institutional ownership, board size, ownership concentration, foreign directors, and board activity. Discretionary accrual is used as the proxy of earnings management. 101 manufacturing companies which listed in Indonesia Stock Exchange during period year 2014 to year 2016, was used as sample using purposive sampling method. This research uses multiple regression as a method of data analysis. The result shows that audit committee financial expertise, institusional ownership, board size, ownership concentration and foreign directors have no effect to earnings management, while board activity affects earnings management.
\end{abstract}

Keywords: Earnings Management, Board Size, Audit Committee Financial Expertise, Discretionary Accrual 


\section{Pendahuluan}

Laporan keuangan yang merupakan objek dari praktik manajemen laba merupakan cerminan kinerja perusahaan dalam jangka pendek dan juga jangka panjang. Manajemen laba adalah salah satu pilihan yang dilakukan oleh manajemen sebuah perusahaan di dalam menentukan kebijakan akuntansi yang mempengaruhi pelaporan laba untuk mencapai tujuan tertentu (Scott, 2015). Manipulasi laporan keuangan dilakukan agar laporan keuangan perusahaan menjadi baik sehingga dapat membuat para investor dan kreditor baru tertarik untuk berinvestasi di perusahaan tersebut. Manipulasi laporan keuangan juga membuat para investor dan kreditor lama merasa puas atas kinerja manajemen pada periode tertentu. Tindakan yang dilakukan di atas dikenal dengan nama manajemen laba. Manajemen laba memiliki sisi positif dan sisi negatif, dari sisi positif manajemen laba mengantisipasi kejadian yang tidak terduga-duga, sedangkan jika dari sisi negatif manajemen laba dipakai untuk keperluan manajemen mendapatkan bonus atas kinerja perusahaan yang telah dimanipulasi, karena manajemen laba yang ditujukan untuk tujuan buruk, laporan keuangan tidak menggambarkan keadaan perusahaan yang sesungguhnya sehingga terjadi kasus manajemen laba.

Kasus di Indonesia sendiri mengenai manajemen laba seperti yang dilaporkan oleh Bapepam terjadi pada PT Kimia Farma pada tahun 2001 karena "kesalahan pencatatan" laporan keuangan. Kimia Farma melakukan markup pada laba bersih dalam laporan keuangan periode 2001. Dalam laporan tersebut, Kimia Farma berhasil me-mark up laba sebesar Rp 132 miliar yang sebenarnya hanya meraih untung sebesar Rp 99 miliar (Syahrul 2002). Selain Kimia Farma, Bank Lippo juga memberikan laporan berbeda ke publik dan BEI (Bursa Efek Indonesia) yang diduga karena ada manipulasi yang dilakukan oleh pihak manajemen. Dalam laporan keuangan per 30 September 2002 yang disampaikan ke publik 28 November 2002 disebutkan total aktiva perseroan $\mathrm{Rp}$ 24 triliun dan laba bersih Rp 98 miliar. Namun dalam laporan ke BEI pada 27 Desember 2002 total aktiva perusahaan berubah menjadi $\mathrm{Rp} 22,8$ triliun rupiah (turun $\mathrm{Rp} 1,2$ triliun) dan perusahaan merugi bersih Rp 1,3 triliun (Sumantyo 2003). Tata kelola perusahaan adalah salah satu cara perusahaan dalam meningkatkan efisiensi untuk mengoptimalkan sumber daya perusahaan untuk kesejahteraan bagi pemegang saham. Hal ini diperlukan untuk mendorong terciptanya pasar yang efisien, transparan dan konsisten dengan peraturan perundang-undangan yang telah ditetapkan sebagai upaya guna menjamin kualitas sebuah pelaporan keuangan dari suatu perusahaan. Tata kelola dapat digunakan unuk menjamin laporan keuangan sehingga informasi yang disajikan dapat diandalkan dan dipercaya oleh beberapa pihak yang berkepentingan dalam pengambilan keputusan. Penerapan tata kelola perusahaan yang baik dapat mendorong beberapa hal, antara lain guna meningkatkan manajemen perusahaan secara profesional, transparan dan efisien dan juga meningkatkan fungsi dan wewenang dewan komisaris, dewan direksi, dan pemegang saham.

Banyaknya praktik manajemen laba yang terjadi serta adanya ketidakkonsistenan penelitian yang sudah dilakukan menjadi motivasi untuk dilakukannya penelitian mengenai topik manajemen laba. Dalam penelitian ini akan dibahas mengenai faktor-faktor apa saja yang mempengaruhi praktik manajemen laba dengan cara menganalisa variabel-variabel yang dipilih untuk diteliti. Penelitian ini merupakan pengembangan dari penelitian terdahulu yang dilakukan oleh Aygun et al. (2014). Penelitian ini dimaksudkan untuk menemukan bukti-bukti empiris mengenai faktor-faktor yang mempengaruhi manajemen laba, melalui variabel independen 
yang digunakan yakni, keahlian keuangan komite audit (Audit Committee Financial Expertise), kepemilikan institusional (institutional ownership), ukuran dewan komisairis, direktur berkewarganegaran asing, dan aktivitas dewan komisaris. Penelitian ini berbeda dengan penelitian sebelumnya yang dilakukan oleh Aygun et al (2014), dalam beberapa hal yaitu:

a. Variabel penelitian

Pada penelitian sebelumnya, variabel independen yang digunakan adalah kepemilikan institusional, kepemilikan manajerial dan board size. Selain itu, pada penelitian ini menambahkan tiga variabel independen yaitu, ownership concentration yang diambil dari penelitian Gonzales dan Garcia Meca (2014), board activity dan keahlian keuangan komite audit yang diambil dari penelitian Du et al. (2017). Variabel board size mengacu kepada penelitian Aygun et al. (2014) dan variabel kepemilikan manajerial diganti-kan dengan variabel direktur berkewarganegaraan asing karena variabel kepemili-kan manajerial dinilai akan mengeliminasi banyak sampel perusahaan.

\section{b. Sampel Penelitian}

Sampel penelitian sebelumnya, data sampel yang digunakan adalah perusahaan di Turki yang terdaftar di Istanbul Stock Exchange (ISE), sedangkan dalam penelitian ini melakukan pengambilan sampel perusahaan manufaktur yang terdaftar di Bursa Efek Indonesia (BEI).

c. Tahun data penelitian

Pada penelitian sebelumnya mengguna-kan data tahun 2009 sampai dengan tahun 2013, sedangkan pada penelitian ini menggunakan data tahun 2013 sampai dengan tahun 2016.

Berdasarkan pengembangan penelitian yang dijelaskan dalam latar belakang di atas, maka penelitian ini akan dilakukan dan diberi judul "Pengaruh Tata Kelola Perusahaan Terhadap Manajemen Laba pada Perusahaan Manufaktur yang terdaftar di Bursa Efek Indonesia". Berdasarkan latar belakang tersebut, maka rumusan masalah dalam penelitian ini adalah untuk menguji apakah beberapa variabel yang ditentukan memiliki pengaruh terhadap manajemen laba perusahaan yang terdiri dari:

a. Apakah keahlian keuangan komite audit memiliki pengaruh terhadap manajemen laba?

b. Apakah kepemilikan institusional memiliki pengaruh terhadap manajemen laba?

c. Apakah jumlah dewan komisaris memiliki pengaruh terhadap manajemen laba?

d. Apakah konsentrasi kepemilikan memiliki pengaruh terhadap manajemen laba?

e. Apakah direktur berkewarganegeraan asing memiliki pengaruh terhadap manajemen laba?

f. Apakah aktivitas dewan komisaris memiliki pengaruh terhadap manajemen laba?

\section{Tinjauan Pustaka}

\subsection{Teori Keagenan}

Marpaung dan Latrini (2014) berpendapat bahwa teori agensi adalah hubungan tanggung jawab antara manajemen (agent) dengan pemilik (principal) dalam suatu perusahaan. Principal menilai kinerja agen apabila agen bedasarkan laba yang diperoleh perusahaan, semakin besar laba perusahaan maka semakin besar pula harga saham dan dividen, sehingga agen dianggap memiliki kinerja yang baik dan mendapat insentif yang tinggi. Sedangkan agen memenuhi tuntutan principal dengan cara memainkan beberapa kondisi perusahaan dengan cara melanggar peraturan maupun tidak melanggar peraturan (Abukosim et al. 2014).

\subsection{Manajemen Laba}

Manajemen laba merupakan keputusan yang dilakukan oleh manajer dalam memilih kebijakan akuntansi tertentu yang dianggap dapat digunakan untuk mencapai 
tujuan yang diinginkan guna meningkatkan laba dan juga mengurangi tingkat kerugian yang ada di laporan keuangan. Kebijakan akuntansi yang dapat dipilih tersebut adalah penggunaan accrual dalam menyusun laporan keuangan (Agustia 2013). Manajemen laba digolongkan menjadi 2 bagian, yang pertama dapat dilihat sebagai perilaku oportunistik manajer guna memaksimalkan kegunaannya dalam menghadapi kontrak kompensasi, kontrak hutang dan political costs (opportunistic earnings management). Manajemen laba dapat dipandang dari perspektif efficient contracting (efficient earnings management), di mana manajemen laba memberi manajer suatu keleluasaan dalam melindungi diri mereka dan perusahaan guna mengantisipasi kejadian-kejadian yang tidak terduga untuk keuntungan pihak-pihak yang terlibat di dalam kontrak yang berlaku (Scott, 2015).

\subsection{Corporate Governance}

Corporate governance mengacu pada aturan, proses dan hukum di mana perusahaan beroperasi, dikontrol dan diatur. Corporate governance juga mendefinisikan hak dan tanggung jawab dari pelaku dalam perusahaan seperti stakeholder, dewan direksi, karyawan dan manajer, juga pemegang kepentingan lain. Struktur corporate governance yang baik akan memberikan keuntungan kepada seluruh pemegang kepentingan perusaha-an dengan menjamin bahwa perusahaan dijalankan dengan sah dan etis, sesuai dengan praktik terbaik dan tunduk pada semua peraturan perusahaan (Gitman dan Zutter, 2012).

Terdapat 2 mekanisme tata kelola (corporate governance) yaitu, mekanisme satu kamar (one-tier) di mana peran dewan pengawas dan dewan pelaksana dijadikan dalam satu wadah yang disebut sebagai board of directors. Negara-negara yang menganut one tier system adalah Amerika Serikat dan Inggris. (2) mekanisme dua kamar (two tier). Dalam hal ini Dewan Komisaris tidak diperkenankan terlibat dalam tugas manajemen dan tidak dapat mewakili perusahaan dalam transaksi dengan pihak ketiga. Anggota Dewan Komisaris diangkat dan diganti dalam Rapat Umum Pemegang Saham (RUPS). Negara yang menganut Two Tiers System antara lain Denmark, Jerman, Belanda, dan Jepang. Hal ini menyebabkan sistem hukum Indonesia yang mengadaptasi sistem hukum Belanda menganut mekanisme dua kamar (Two Tiers) untuk struktur dewan dalam perusahaan (FCGI, 2014).

\subsection{Keahlian Keuangan Komite Audit}

Definisi keahlian kuangan juga dinyatakan lebih jelas dalam Securities and Exchange Commission (SEC) 2003b yang merupakan pengungkapan yang diwajibkan berdasarkan Sarbanes Oxley Act of 2002. Dijelaskan bahwa keahlian keuangan dibuktikan dengan, "(1) pendidikan dan pengalaman sebagai kepala keuangan, kepala akuntansi, pengendali atau pengatur, akuntan publik atau auditor atau pengalaman dalam satu atau lebih posisi yang melibatkan kinerja dari fungsi serupa; (2) pengalaman secara aktif mengawasi kepala keuangan, kepala akuntansi, pengendali, akuntan publik, auditor, atau petugas dengan fungsi serupa, (3) pengalaman mengawas atau menilai kinerja perusahaan atau akuntan publik mengenai persiapan, pemeriksaan atau evaluasi laporan keuangan; atau (4) pengalaman lainnya yang relevan.”

Fungsi komite audit adalah sebagai dewan pengawas namun tidak bertindak sebagai pengambil keputusan operasional karena tugas tersebut menjadi tanggung jawab dewan direksi. Komite audit harus memiliki latar belakang akuntansi dan keuangan agar efektivitas fungsi pengawasan dapat lebih ditingkatkan. Chtourou et al. (2001) menjelaskan bahwa tingkat keahlian komite audit yang lebih tinggi menyebabkan pengawasan yang lebih tinggi. Manajemen laba jarang sekali terjadi pada perusahaan-perusahaan yang dijalankan oleh komite yang memiliki latar 
belakang keuangan (Xie et al., 2003). Pengetahuan dalam bidang akuntansi dan keuangan akan berguna untuk dewan komisaris dalam memahami laporan keuangan serta masalah-masalah yang muncul dalam laporan keuangan serta meminimalkan manajemen laba.

\subsection{Kepemilikan Institusional}

Kepemilikan institusional adalah kepemilikan saham yang dimiliki oleh pihak institusi, yang dalam hal ini antara lain adalah perusahaan asuransi, bank, LSM dan perusahaan swasta (Suriyani et al. 2015). Perusahaan institusi akan lebih cepat mengetahui apabila terjadi kecura-ngan pada suatu perusahaan, karena sistem akuntansi perusahaan institusi lebih baik dan dapat mendeteksi kecurangan dengan cepat dan akurat. Dengan adanya kepemilikan institusional, pihak manaje-men dapat dikendalikan melalui proses pengawasan secara efektif sehingga dapat mengurangi praktik manajemen laba (Sari dan Asyik, 2013).

\subsection{Ukuran Dewan Komisaris}

Dewan komisaris dipilih oleh para pemegang saham dalam RUPS yang diharapkan dapat mewakili kepentingan para pemegang saham. Peran komisaris sangat penting dan cukup menentukan atas keberhasilan penerapan good corporate governance. Komitmen penuh dari komisaris diperlukan agar penerapan good corporate governance dapat berjalan dengan lancar sesuai dengan harapan (Sari dan Asyik, 2013). Berdasarkan teori keagenan, dewan komisaris dianggap sebagai alat pengendali Finternal paling tinggi (Prastiti dan Meiranto, 2013). Pengawasan yang dilakukan oleh dewan komisaris akan menambah kepercayaan pemegang saham bahwa manajemen telah bertindak sesuai dengan kepentingan pemegang saham. Dewan komisaris diangkat oleh pemegang saham sehingga harus mewakili kepentingan para pemegang saham dalam mengawasi tindakan manajemen tersebut. Dalton et al. (1999) berpendapat bahwa anggota dewan komisaris yang lebih besar memberikan lebih banyak keuntungan bagi perusahaan melalui alternatif berbagi pengawasan yang dapat mengurangi kejadian manajemen laba (Swastika, 2013).

\subsection{Konsentrasi Kepemilikan}

Kepemilikan saham dapat dikategorikan terkonsentrasi jika sebagian besar saham dimiliki oleh sebagian kecil individu ataupun kelompok, sehingga pemegang saham tersebut memiliki jumlah saham yang dominan dibandingkan dengan pemilik saham yang lain (Dallas, 2004). Manajemen dapat dikendalikan oleh investor melalui proses monitoring sehingga dapat mengurangi manajemen laba (Cibro, 2010).

\subsection{Direktur Berkewarganegaran Asing}

Perkembangan perekonomian di Indone-sia berkembang begitu pesat. Persaingan antar individu ataupun perusahaan juga semakin ketat. Hal ini dibuktikan dengan akan dilakukan pengesahan MEA (Masyarakat Ekonomi ASEAN) 2015 oleh pihak pemerintah Indonesia. Pengesahan MEA 2015 akan membuka kesempatan bagi seluruh pekerja dibidang ekonomi untuk dapat lebih mudah melakukan akses ke luar negeri. Dalam beberapa tahun terakhir pergerakan Warga Negara Asing (WNA) di Indonesia terlihat berkembang pesat. Di berbagai bidang pekerjaan terdapat sejumlah Tenaga Kerja Asing (TKA) yang menjabat sebagai CEO. Dengan adanya anggota dewan komisaris berkewarganegaraan asing menunjukkan bahwa perusahaan telah menuju arah globalisasi dan pertukaran informasi dalam hubungan internasional (Winoto dan Supatmi, 2014).

Dengan adanya anggota dewan komisaris berkewarganegaraan asing mampu meyakinkan investor luar bahwa perusahaan telah dikelola secara profesional. Selain itu dapat memicu keterbukaan informasi dengan harapan kredibilitas perusahaan akan meningkat (Randoy et al. 2006). Hal 
tersebut maka dapat disimpulkan bahwa semakin banyak direktur berkewarganegaran asing di suatu perusahaan diharapkan dapat berkerja dengan profesional dalam melakukan tugasnya untuk meminimalkan praktik manajemen laba.

\subsection{Aktivitas Dewan Komisaris}

Dalam tugasnya untuk mengawasi manajemen, rapat dewan komisaris merupakan sarana komunikasi serta koordinasi antar anggota dewan komisaris. Rapat dewan komisaris membahas arah serta strategi suatu perusahaan, evaluasi kebijakan yang telah dilakukan oleh manajemen, dan juga mengatasi masalah konflik kepentingan (FCGI, 2014). Peran dewan komisaris dapat memiliki pengaruh untuk menekan manajemen yang melakukan manajemen laba. Jika rapat dewan komisaris semakin sering diadakan, maka diharapkan monitoring yang dilakukan oleh dewan komisaris akan semakin baik (Machmuddah, 2015).

\section{Metode Penelitian}

Bentuk penelitian yang digunakan dalam penelitian ini dikategorikan sebagai penelitian kausalitas. Tujuan dari penggunaan metode kausalitas dalam penelitian ini adalah untuk mengetahui sebab akibat hubungan antara variabel independen yaitu kepemilikan manajerial, kepemilikan institusional, ukuran dewan komisaris, konsentrasi kepemilikan, dewan komisaris independen, dan aktivitas dewan komisaris sebagai faktor yang mempengaruhi terhadap variabel dependen yaitu manajemen laba. Populasi yang akan digunakan dalam penelitian ini adalah perusahaan yang terdaftar di Bursa Efek Indonesia (BEI). Unit analisis yang digunakan dalam penelitian ini adalah perusahaan. Sampel yang digunakan dalam penelitian ini adalah perusahaan yang dipilih dengan menggunakan teknik purposive sampling.

Jenis data yang akan diteliti dalam penelitian ini adalah data yang bersifat sekunder yang berasal dari Bursa Efek Indonesia (BEI), data tersebut diambil melalui website www.idx.co.id yang merupakan situs resmi yang dikelola oleh Bursa Efek Indonesia (BEI). Data-data yang digunakan terdiri dari laporan tahunan dan laporan keuangan perusahaan manufaktur yang sudah diaudit pada tahun 2014 sampai 2016. Pemilihan BEI sebagai sumber pengambilan data dalam penelitian ini adalah karena Bursa Efek Indonesia merupakan bursa efek terbesar dan terlengkap di Indonesia. Teknik pengumpulan data dilakukan dengan cara analisis kuantitatif, dengan menggunakan statistik parametrik. Tujuan dari analisis data adalah untuk mendapatkan informasi yang akurat yang dapat digunakan dalam menyelesaikan masalah dan membandingkan hasil tersebut dengan hipotesis yang telah dibuat sebelumnya sehingga dapat membuat kesimpulan dan saran yang dibutuhkan. 


\section{Hasil dan Pembahasan}

Pemilihan sampel pada penelitian ini dilakukan dengan menggunakan metode purposive sampling. Kriteria pemilihan sampel pada penelitian ini dapat dilihat pada tabel 1 di bawah ini:

Tabel 1. Kriteria Pemilihan Sampel Penelitian

Sumber: Diolah Penulis

\begin{tabular}{llcc}
\hline No. & \multicolumn{1}{c}{ Keterangan } & Perusahaan & Jumlah Data \\
\hline 1. & $\begin{array}{l}\text { Perusahaan manufakur yang secara konsisten terdaftar di } \\
\text { Bursa Efek Indonesia selama tahun 2014 - tahun 2016 }\end{array}$ & 138 & 414 \\
\hline 2. & $\begin{array}{l}\text { Perusahaan yang tidak membuat laporan keuangan yang } \\
\text { berakhir pada tanggal 31 Desember }\end{array}$ & $(2)$ & $(6)$ \\
\hline 3. & $\begin{array}{l}\text { Perusahaan yang tidak menampilkan laporan keuangan } \\
\text { dengan menggunakan mata uang Rupiah }\end{array}$ & $(29)$ & $(87)$ \\
\hline 5. & $\begin{array}{l}\text { Perusahaan tidak memiliki data kepemilikan } \\
\text { institusional }\end{array}$ & $(6)$ & $(18)$ \\
\hline & Jumlah sampel yang digunakan & 101 & 303 \\
\hline
\end{tabular}

Pada tabel di atas dapat dilihat bahwa perusahaan manufaktur yang secara konsisten terdaftar di Bursa Efek Indonesia selama tahun 2013-2016 sebanyak 138 perusahaan, sebanyak 2 perusahaan tidak menerbitkan laporan keuangan pada tanggal 31 Desember, sebanyak 29 perusahaan tidak menyajikan laporan keuangan dengan menggunakan mata uang Rupiah, dan sebanyak 6 perusahaan tidak memiliki data kepemilikan institusional. Jumlah sampel yang digunakan dalam penelitian ini berjumlah 101 perusahaan atau 303 observasi.

Hasil uji $t$ dapat dilihat pada tabel 2 berikut ini:

Tabel 2. Hasil Uji $t$

Sumber: Hasil pengolahan data dengan SPSS 21

\begin{tabular}{lcccc}
\hline \multicolumn{1}{c}{ Model } & B & $\mathbf{T}$ & Signifikansi & Kesimpulan \\
\hline (Constant) & $-0,023$ & $-0,731$ & 0,466 & \\
\hline EXPERTISE & $-0,047$ & $-1,969$ & 0,050 & $\mathrm{Ha}_{1}$ tidak diterima \\
\hline INST & $-0,003$ & $-0,079$ & 0,937 & $\mathrm{Ha}_{2}$ tidak diterima \\
\hline BOARD & 0,003 & 0,694 & 0,489 & $\mathrm{Ha}_{3}$ tidak diterima \\
\hline OWNCON & 0,042 & 1,433 & 0,153 & $\mathrm{Ha}_{4}$ tidak diterima \\
\hline FOREIGN & 0,023 & 1,618 & 0,107 & $\mathrm{Ha}_{5}$ tidak diterima \\
\hline ACT & 0,002 & 2,395 & 0,017 & $\mathrm{Ha}_{6}$ diterima \\
\hline
\end{tabular}


Pada tabel 2 dapat dirumuskan persamaan regresi berganda sebagai berikut:

$\mathrm{EM}=-0,023-0,047 \mathrm{AFE}-0,003 \mathrm{INST}+$ 0,003 BOARD + 0,042 CON $-0,023$ FOREIGN $+0,002$ ACT $+\varepsilon$

Hasil penelitian menunjukkan bahwa keahlian keuangan komite auditmemiliki nilai signifikansi sebesar 0,050 di mana nilai ini lebih besar sama dengan dari 0,05 , maka $\mathrm{Ha}_{1}$ tidak diterima artinya keahlian keuangan komite audit tidak memiliki pengaruh terhadap manajemen laba. Hal ini dapat terjadi diduga karena penempatan anggota komite audit yang memiliki keahlian keuangan hanya didasarkan untuk memenuhi regulasi yang ada (Khomsiyah, 2005).

Hasil penelitian menunjukkan bahwa kepemilikan institusional memiliki nilai signifikansi sebesar 0,937 di mana nilai ini lebih besar dari 0,05 , maka $\mathrm{Ha}_{2}$ tidak diterima artinya kepemilikan institusional tidak memiliki pengaruh terhadap manajemen laba. Hal ini disebabkan karena komisaris independen ditunjuk oleh pemegang saham yang terbanyak dalam RUPS sehingga jika tidak sesuai dengan keputusan pemilik, maka perusahaan dapat melakukan penggantian, sehingga meskipun komposisi dewan komisaris independen pada perusahaan relatif besar, tetapi mereka tidak dapat benar-benar independen dalam melaksanakan tugas dan pengawasannya karena dibatasi oleh peraturan dan kebijakan dari pemegang saham yang terbanyak. Hal ini menyebabkan, komisaris independen tidak dapat mendorong pelaksanaan tata kelola (good corporate governance) secara optimal dalam membatasi praktik manajemen laba (Agustia, 2013).

Hasil penelitian menunjukkan bahwa jumlah dewan komisaris mempunyai nilai signifikansi sebesar 0,489 di mana nilai ini lebih besar dari 0,05 , maka $\mathrm{Ha}_{3}$ tidak diterima yang berarti jumlah dewan komisaris tidak memiliki pengaruh terhadap manajemen laba. Hal ini disebabkan oleh tingkat efektivitas dewan pengurus dalam mengawasi tindakan manajemen yang tidak hanya dapat dilihat dari jumlah anggotanya saja, tetapi juga dapat dilihat dari faktor lain seperti komposisi, kompetensi dan pembuatan keputusan dari setiap anggota yang terdaftar dalam dewan pengurus (Natalia, 2013). Hasil penelitian menunjukkan bahwa konsentrasi kepemilikan mempunyai nilai signifikansi sebesar 0.153 di mana nilai ini lebih besar dari 0,05 , maka $\mathrm{Ha}_{4}$ tidak diterima artinya, kepemilikan terkonsentrasi masih belum dapat membatasi perilaku oportunistik manajemen. Hal ini disebabkan oleh: (1) terdapat pandangan yang menyatakan bahwa pemilik sementara lebih fokus terhadap laba jangka pendek dengan cara melakukan manipulasi laba, (2) institusi yang bergerak di dalam bidang keuangan tidak dapat mengetahui apakah dalam perusahaan terdapat tindakan manajemen laba atau tidak, (3) Emiten yang dianalisis termasuk memiliki struktur kepemilikan yang hanya berkonsentrasi pada institusi yang memiliki saham besar sehingga mempunyai kemampuan dalam melakukan pengaruh terhadap jalannya perusahaan serta mengatur proses penyusunan laporan keuangan, (4) terpusatnya kepemilikan akan membuat manajer terikat dalam memenuhi target keuntungan dari para investor, sehingga manajer akan tetap terlibat dalam tindakan manipulasi laba (Rachmawati, 2017).

Hasil penelitian menunjukkan bahwa direktur berkewarganegaran asing memiliki nilai signifikansi sebesar 0,107 di mana nilai ini lebih besar dari 0,05 , maka $\mathrm{Ha}_{5}$ tidak diterima artinya direktur berkewarganegaraan asing tidak berpengaruh terhadap manajemen laba. Direktur berkewarganegaraan asing tidak menjadi indikasi suatu perusahaan akan melakukan praktik manajemen laba. Hal ini dapat terjadi karena hubungan yang tidak baik antara dewan komisaris berkewarganegaraan asing dan manajemen laba dilemahkan untuk perusahaan-perusahaan BUMN dan 
keberagaman dewan nasional meningkatkan pengambilan keputusan perusahaan dan meningkatkan minat investor (Du et al. 2017).

Hasil penelitian menunjukkan bahwa aktivitas dewan memiliki nilai signifikansi sebesar 0,017 di mana nilai ini lebih kecil dari 0,05 , Nilai koefisien sebesar 0,002 menjelaskan bahwa aktivitas dewan komisaris secara positif mempengaruhi manajemen laba, maka $\mathrm{Ha}_{6}$ diterima artinya aktivitas dewan komisaris berpengaruh terhadap manajemen laba. Rapat dewan komisaris merupakan sarana komunikasi dan koordinasi antara anggota dewan komisaris dalam melaksanakan tugasnya untuk mengawasi manajemen. Pada rapat tersebut juga dibahas arah dan strategi perusahaan, evaluasi kebijakan yang telah diambil oleh manajemen, serta mengatasi masalah konflik kepentingan (FCGI, 2014), sehingga rapat dewan komisaris merupakan hal yang penting dalam melaksanakan tugasnya di bidang pengawasan dan pengendalian. Dengan semakin seringnya diadakan rapat dewan komisaris, mekanisme pengawasan dapat dilakukan secara efektif dan mampu membatasi manajer sehingga praktik manajemen laba di dalam sebuah perusahaan dapat ditiadakan (Aryani, 2011).

Rapat yang efektif seharusnya dapat memberikan kesempatan kepada semua pihak dalam mengemukakan pendapat dan berdiskusi secara terbuka tanpa mendapatkan tekanan dari pihak lain. Rapat yang efektif tidak terjadi karena budaya ketimuran orang Indonesia, yaitu adanya rasa khawatir terhadap akibat di masa yang akan datang dan terdapat satu atau dua orang yang mendominasi jalannya rapat (Muntoro, 2006).

\section{Kesimpulan}

Berdasarkan analisis dan pembahasan tentang beberapa faktor yang mempengaruhi manajemen laba pada perusahaan manufaktur yang terdaftar di Bursa Efek
Indonesia dari tahun 2014 sampai dengan tahun 2016, maka dapat disimpulkan sebagai berikut:

a. Keahlian keuangan komite audit tidak mempunyai pengaruh terhadap manajemen laba. Hasil penelitian ini tidak sesuai dengan penelitian yang dilakukan oleh Boldato et al. (2014) yang menyatakan bahwa kepemilikan manajerial memiliki pengaruh terhadap manajemen laba.

b. Kepemilikan institusional tidak mempunyai pengaruh terhadap manajemen laba. Hasil penelitian ini sesuai dengan hasil penelitian yang dilakukan oleh Gonzalez dan Garcia-Meca (2014) dan Susanto (2013). Namun tidak sesuai dengan penelitian yang dilakukan oleh Aygun et al. (2014) yang menyatakan bahwa kepemilikan institusional memiliki pengaruh terhadap manajemen laba.

c. Jumlah dewan komisaris tidak memiliki pengaruh terhadap manajemen laba. Hasil penelitian ini sejalan dengan hasil penelitian yang menyatakan bahwa jumlah dewan komisaris memiliki pengaruh terhadap manajemen laba (Sari dan Putri, 2014) namun tidak sejalan dengan penelitian yang dilakukan oleh Aygun et al. (2014), serta Prastiti dan Meiranto (2013) yang menyatakan bahwa jumlah dewan komisaris tidak memiliki pengaruh terhadap manajemen laba.

d. Kepemilikan terkonsentrasi tidak memiliki pengaruh terhadap manajemen laba. Hasil penelitian ini sesuai dengan hasil penelitian yang dilakukan oleh Nuryaman (2009), namun tidak sesuai dengan penelitian yang dilakukan oleh Ali et al. (2009) yang menyatakan bahwa kepemilikan terkonsentrasi memiliki pengaruh terhadap manajemen laba.

e. Direktur berkewarganegaraan asing tidak memiliki pengaruh terhadap manajemen laba. Hasil penelitian ini tidak sesuai dengan penelitian yang dilakukan oleh Du et al. (2017) yang 
menyatakan bahwa ukuran perusahaan memiliki pengaruh terhadap manajemen laba.

f. Aktivitas dewan komisaris memiliki pengaruh terhadap manajemen laba. Hasil penelitian ini sejalan dengan hasil penelitian yang menyatakan bahwa aktivitas dewan komisaris memiliki pengaruh terhadap manajemen laba (Gonzales dan Gracia-Meca (2014), namun hasil penelitian ini tidak sejalan dengan hasil penelitian oleh Ebrahim (2007) yang menyatakan bahwa ukuran komite audit memiliki pengaruh terhadap manajemen laba.

\section{Daftar Pustaka}

Abukosim, M., Ferina, I.S., \& Nurcahaya, C. (2014). Ownership structure and firm values: empirical study on Indonesia manufacturing listed companies. Journal of Arts, Science and Commerce, 5(4), 1-14.

Agustia, D. (2013). Pengaruh faktor good corporate governance, free cash flow, dan leverage terhadap manajemen laba. Jurnal Akuntansi dan Keuangan, 15(1), 27-42.

Aygun, M., Suleyman, I.C, \& Mustafa, S. (2014). The effect of corporate ownership structure and board size on earnings management: evidence from Turkey. International Journal of Business and Management, 9(12), 123132.

Bapepam, L.K. (2012). Peraturan Bapepam X.K.6 (Lampiran Keputusan Ketua Bapepam Nomor Kep-431/BL/2012/ Tanggal 1 Agustus 2012) Penyampaian laporan tahunan emiten atau perusahaan publik. Jakarta: Badan Pengawas Pasar Modal dan Lembaga Keuangan.

Du, X., Wei J., Shaojuan, L. (2017). Do foreign directors mitigate earnings management? evidance from China.
International Journal Accounting, 145150.

Ebrahim, A. (2007). Earnings management and board activity: an additional evidence. Review of Accounting and Finance 6(1).

FCGI. (2014). Corporate Governance: Tata Kelola Perusahaan, (3) 4-8. Jakarta.

Gonzales, J. S. \& Emma, G. M. (2014). Does corporate governance influence earning management in Latin American market. J Bus Ethics, 121, 419-440.

Natalia, D. (2013). Pengaruh mekanisme good corporate governance terhadap praktik earning management badan usaha sektor perbankan. Jurnal Ilmiah Mahasiswa Universitas Surabaya. 2(1).

Nuryaman. (2009). Pengaruh konsentrasi kepemilikan, ukuran perusahaan, dan mekanisme corporate governance terhadap manajemen laba. Jumal Akuntansi dan Keuangan Indonesia, 6(1).

Machmuddah, Z. (2015). Corporate Governance Mechanisms, Manajemen Laba Dan Kinerja Keuangan 3(1), Janari-Juni 2015. Universitas Dian Nuswantoro.

Marpaung, C. O. \& Latrini, Y. (2014). Pengaruh Dewan Komisaris Independen, Komite Audit, kualitas audit, dan kepemilikan manajerial pada perataan laba. E-Jurnal Akuntansi Universitas Udayana 7(2), 279-289.

Prastiti, A. \& Wahyu, M. (2013). Pengaruh karakteristik Dewan Komisaris dan Komite Audit terhadap manajemen laba. Diponegoro Journal of Accounting, 2(4), 1-12.

Rachmawati, E. (2017). Pengaruh Konsentrasi Kepemilikan, Ukuran Perusahaan, Asimetri Informasi, Leverage dan Corporate Governance Terhadap Manajemen Laba. (Studi Pada Perusahaan yang Terdaftar di Bursa Efek Indonesia Periode 2013-2015). Fakultas Ekonomi dan 
Bisnis. Universitas Muhammadiyah Surakarta.

Randoy, T., Thomsen, S., \& Oxelheim, L. (2006). A Nordic perspective on corporate board diversity. Age, 390, 0-5428.

Sari, D. A., Edyanus, H. H., \& Ahmad, F. F., (2014). Pengaruh mekanisme good corporate governance dan financial distress terhadap earning management (studi empiris pada perusahaan manufaktur yang terdaftar di Bursa Efek Indonesia). Economic Faculty, Universitas of Riau.

Sari, S. R. \& Nur, F.A. (2013). Pengaruh leverage dan mekanisme good corporate governance terhadap manajemen laba. Jurnal Ilmu Riset Akuntansi, 2(6).

Scott, W. R. (2015). Financial Accounting Theory. Toronto: Pearson.

Sumantyo, R. (2003). Kasus Bank Lippo dan Degradasi Kepercayaan Publik. Available from: http://www.suaramer deka.com/harian/ 0302/24/eko1.html.

Suriyani, P. P., Yuniarta, G. A. \& Atmadja, A. T. (2015). Faktor-faktor yang mempengaruhi manajemen laba (studi empiris pada perusahaan manufaktur yang terdaftar di BEI Periode Tahun 2008-2013). E-Journal S1 Ak Universitas Pendidikan Ganesha, 3(1).

Swastika \& Dwi, L. T. (2013). Corporate governance, firm size, and earnings management: evidence in Indonesia Stock Exchange. IOSR Journal of Business and Management, 14(4), 77-82.

Syahrul, Y. (2002). Bapepam: Kasus Kimia Farma Merupakan Tindak Pidana. Tempo interaktif, Available from: http://tempo.co.id/hg/ekbis/2002/11/04/ brk,20021104-36,id.html.

Xie, B., et al. (2003). Earnings management and corporate governance: the role of the board and the audit committee. Journal of Corporate Finance 9(6), 295-316. 